\title{
Screening of wild fruit trees with gastroprotective activity in different experimental models
}

\author{
Luciane Angela Nottar NESELLO, Adriana CAMPOS, Roseane Leandra da ROSA, \\ Sérgio Faloni de ANDRADE and Valdir CECHINEL FILHO
}

Received 18/10/2016 Accepted 22/12/2016

\begin{abstract}
Background - Given the increase of people with gastrointestinal disorders, the search for alternative treatments with fewer side effects is vital, as well as the demand for food or plants that can help protect the stomach. Objective - The aim of this study was to evaluate the gastroprotective action of the extracts of wild fruit trees of Myrcianthes pungens (guabiju); Inga vera Willd. (ingá-banana) and Marlierea tomentosa Cambess. (guarapuruna) in in vivo pharmacological models. Methods - The different parts of the fruits were separately subjected to a process of extraction by methanol. Two experimental pharmacological models were conducted in mice; the gastric ulcer model induced by non-steroidal anti-inflammatory (indomethacin), and the gastric ulcer model induced by ethanol/ $\mathrm{HCl}$, which allowed us to evaluate the gastroprotective activity of the extracts at a dose of $250 \mathrm{mg} / \mathrm{kg}$. Subsequently, the total lesion area $\left(\mathrm{mm}^{2}\right)$ and relative lesion area (\%) were determined. Results - The results showed significant gastroprotective activity against the aggressive agents used - ethanol and indomethacin - for all the extracts tested. Conclusion - It is assumed that the fruits have bioactive compounds such as antioxidant substances that act on the prostaglandin levels, protecting them from the damage caused by ethanol and indomethacin. These results prompt further studies to isolate and identify the active properties.
\end{abstract}

HEADINGS - Gastrointestinal diseases. Phytochemicals. Ethanol. Indomethacin.

\section{INTRODUCTION}

Dietary patterns have undergone drastic changes in recent years, due to the replacement of fresh foods by processed foods, and unfortunately, these changes have resulted in an increasing number of people becoming affected by diseases of the digestive tract, such as gastritis, ulcers and carcinomas ${ }^{(11,13)}$.

The development of gastritis, ulcers and other gastric disorders is not well understood. They may be associated with endogenous factors such as autoimmune diseases and gastric hypersecretion and exogenous factors such as stress, alcohol, caffeine, nonsteroidal anti-inflammatory drug (NSAID), infection by Helicobacter pylori, among others ${ }^{(7)}$.

Given the large number of people affected by gastritis and the possibility of the evolution to clinical ulcer, the search for new drugs and alternative treatments with fewer adverse side effects is vital, as well as the demand for food or plants that can help protect the stomach ${ }^{(11)}$.

Several experimental studies have highlighted the functional benefits of fruits, vegetables and plants, due to the presence of bioactive compounds that can be used in the prevention and treatment of various diseases ${ }^{(3,9,11,17)}$.

Considering the evidence of promising active principles, such as flavonoids and terpenes, present in wild fruit trees, we have selected the following species to evaluate the gastroprotector potential: Myrcianthes pungens, Marlierea tomentosa and Inga vera.

Myrcianthes pungens popularly known as "guabiju", belongs to the Myrtaceae family. This plant is found mainly in South
America, where it is used in popular medicine to regularize intestinal functions ${ }^{(2,6)}$.

Marlierea tomentosa Cambess, a tree that grows in the coastal forests of Brazil, is popularly known as "guarapuruna" and also belongs to the Myrtaceae family, which is known to present flavonoids and terpenes with analgesic properties ${ }^{(1,12,14)}$.

Inga vera Willd, popularly known as "ingá-banana", grows in the Atlantic Forest and areas of riparian vegetation. It belongs to the family Fabaceae and subfamily Mimosoideae, with about 40 genera and $350-400$ species $^{(5)}$.

The aim of this study was to evaluate the gastroprotective action of the extracts of wild fruit trees of Myrcianthes pungens (guabiju); Inga vera Willd. (ingá-banana) and Marlierea tomentosa Cambess. (guarapuruna) in vivo pharmacological models.

\section{METHODS}

\section{Plant material and preparation of extracts}

Selected wild fruit trees were collected in February 2013 in the state of Santa Catarina, Brazil and identified by Dr. Oscar B. Iza (Universidade do Vale do Itajai).

Leaves and seeds from Myrcianthes pungens, pulp and seeds from Inga vera, peel and seeds from Marlierea tomentosa, were cut into small pieces and extracted by maceration with methanol at room temperature for approximately seven days. The resulting macerates were filtered and concentrated under reduced pressure, using a rotatory evaporator, to yield the respective crude methanol extracts.

Declared conflict of interest of all authors: none

Disclosure of funding: no funding received

Programa de Pós-Graduação em Ciências Farmacêuticas e Núcleo de Investigações Químico-Farmacêuticas, Universidade do Vale do Itajaí (UNIVALI), Itajaí, SC, Brasil.

Correspondence: Valdir Cechinel Filho. Universidade do Vale do Itajaí (UNIVALI). Rua Uruguai, 458 - CEP: $88302-901$ - Itajaí, SC, Brasil. E-mail: cechinel@univali.br 


\section{Drugs, reagents, and solvents}

Indomethacin and cimetidine were purchased from SigmaAldrich (St. Louis, MO, USA). All the other reagents and solvents used were of analytical grade.

\section{Evaluation of gastroprotective activity}

Male Balb/c mice (20-35 g) were provided by the Central Animal House of the Universidade do Vale do Itajaí (UNIVALI) (Itajaí, $\mathrm{SC}$, Brazil). The animals were housed in groups of five, in standard cages, at room temperature $\left(22 \pm 2^{\circ} \mathrm{C}\right)$ with $12 \mathrm{~h}$ dark $/ 12 \mathrm{~h}$ light cycles, and received food and water ad libitum.

Twelve hours prior to the experiments, they were transferred to the laboratory and given only water ad libitum. In all the experiments, the animals were kept in cages with wide-mesh raised floors to prevent coprophagy. The animals used in the present study were housed and cared for in accordance with the Federal Government legislation on animal care. Also, the experiments were authorized by the Ethical Committee for Animal Care of the Universidade do Vale do Itajai (process number 041/13).

\section{Ethanol/HCl-induced ulcer}

The experiment was performed according to the method described by Mizui and Doteuchi ${ }^{(15)}$, with some modifications. After $12 \mathrm{~h}$ of fasting, 48 animals were randomly divided into 8 different groups of 6 animals each and pre-treated orally with cimetidine (positive control - $100 \mathrm{mg} / \mathrm{kg}$ ), vehicle (negative control - distilled water) and the methanol extracts from each part of the plants at a dose of $250 \mathrm{mg} / \mathrm{kg}$. All treatments were administered by gavage.

One hour after treatment, all animals received $0.1 \mathrm{~mL} / 10 \mathrm{~g}$ (body weight) of a $0.3 \mathrm{~mol} / \mathrm{L} \mathrm{HCl}$ in $60 \%$ ethanol solution (ethanol $/ \mathrm{HCl}$ ) to induce gastric ulcer. Another hour later, the animals were sacrificed by cervical dislocation, and the stomachs removed and opened along the greater curvature. The stomachs were gently rinsed with water to remove the gastric contents and blood clots, for subsequent scanning. The images obtained were analyzed using specific "EARP" software to measure each lesion point. The results were expressed as total lesion area $\left(\mathrm{mm}^{2}\right)$ and relative lesion area $(\%)$.

\section{Nonsteroidal anti-inflammatory drug-induced ulcer}

Experiments were carried out according to the method described in Rainsford ${ }^{(18)}$, with a few modifications. After $12 \mathrm{~h}$ of fasting, the animals were randomly divided into different groups of six animals each and pre-treated orally with cimetidine (positive control $-100 \mathrm{mg} / \mathrm{kg}$ ), vehicle (negative control - distilled water) and the methanol extracts from each part of the fruits, at a dose of $250 \mathrm{mg} / \mathrm{kg}$. All treatments were administered orally.

One hour after treatment, all the mice received indomethacin $(100 \mathrm{mg} / \mathrm{kg}$, p.o.) to induce gastric ulcer. Twelve hours after treatment with indomethacin, the animals were sacrificed by cervical dislocation, and the stomachs removed and opened along the greater curvature. The images were scanned and analyzed using image analysis software EARP to determine the number and size of the lesions. The results are expressed as total lesion area $\left(\mathrm{mm}^{2}\right)$ and relative lesion area (\%).

\section{Statistical analysis}

The data are reported as mean \pm standard error of the mean (SEM) and were compared using one-way analysis of variance (ANOVA), followed by Dunnett's pairwise test, and $P$ values $<0.05$ were considered significant.

\section{RESULTS}

The gastroprotective potential of $M$. pungens, $M$. tomentosa and $I$. vera extracts was initially demonstrated by a significant reduction in damaged areas of the stomach when compared with the negative control (Table 1) in rats with ethanol-induced ulcer, a necrotizing agent.

TABLE 1. Effect of oral administration of plant extracts in mice $(n=6)$ subjected to induction of acute ulcer ethanol

\begin{tabular}{lccc}
\hline Treatments & Dose & $\begin{array}{c}\text { Total area of } \\
\text { lesion }\left(\mathrm{mm}^{2}\right)\end{array}$ & $\begin{array}{c}\text { Relative area of } \\
\text { lesion (\%) }\end{array}$ \\
\hline Negative control & $250 \mathrm{mg} / \mathrm{kg}$ & $56.472 \pm 9.315$ & $10.615 \pm 1.273$ \\
M. tomentosa (peel) & $250 \mathrm{mg} / \mathrm{kg}$ & $5.029 \pm 2.36 * *$ & $0,99 \pm 0.47 * *$ \\
M. tomentosa (seed) & $250 \mathrm{mg} / \mathrm{kg}$ & $6.195 \pm 2.52 * *$ & $1.591 \pm 0.62 *$ \\
M. pungens (seed) & $250 \mathrm{mg} / \mathrm{kg}$ & $9.212 \pm 5.57 * *$ & $0.731 \pm 0.41 * *$ \\
M. pungens (leaves) & $250 \mathrm{mg} / \mathrm{kg}$ & $29.529 \pm 11.37 *$ & $2.797 \pm 0.67 *$ \\
I. vera (seed) & $250 \mathrm{mg} / \mathrm{kg}$ & $4.823 \pm 2.27 * *$ & $0.94 \pm 0.39 * *$ \\
I. vera (pulp) & $250 \mathrm{mg} / \mathrm{kg}$ & $3.868 \pm 1.94 * *$ & $0.407 \pm 0.12 * *$ \\
Positive control & $100 \mathrm{mg} / \mathrm{kg}$ & $3.79 \pm 1.01 * *$ & $1.782 \pm 0.62 *$ \\
\hline
\end{tabular}

Results as mean ${ }_{ \pm}$SEM for six rats or mice. Statistical comparison was performed using ANOVA followed by Dunnett's post test. $P<0.05$ and ${ }^{* * *} P<0.01$ compared with the negative control group.

All the extracts were analyzed separately, as the lesion area on the methodology of induction of acute ulcer by ethanol. I. vera extracts showed gastroprotective effect in both studied parts (pulp and seed), which had significant differences when compared to the negative control and to the extracts of M. pungens (leaves and seeds) (Figure 1).

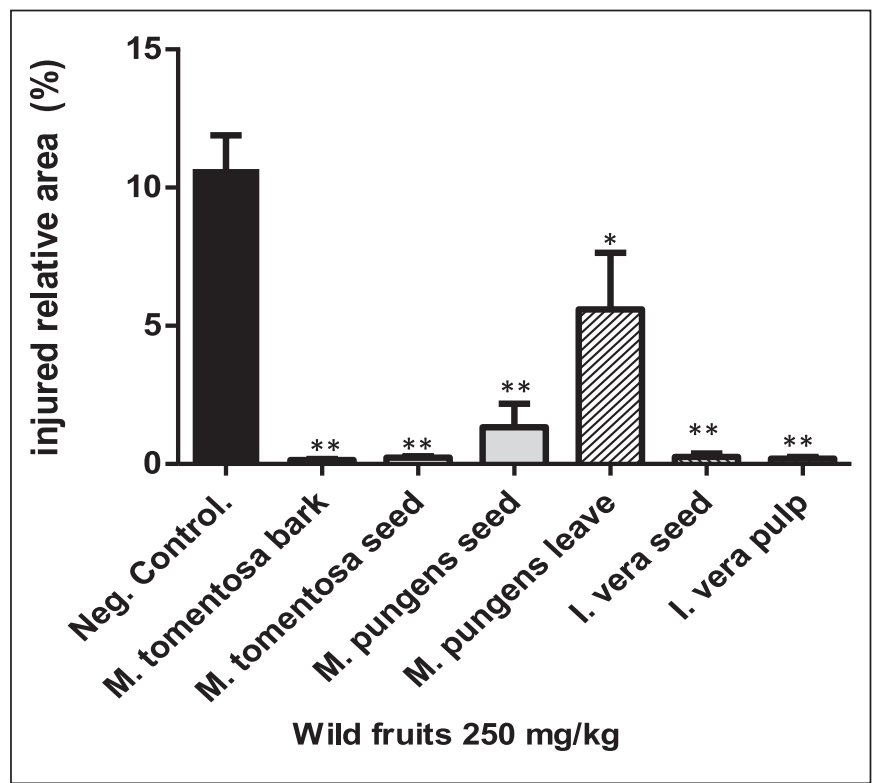

FIGURE 1. Gastroprotective effect of plant extracts $(250 \mathrm{mg} / \mathrm{kg})$ in mice in the ethanol-induced acute ulcer methodology. Results as mean \pm SEM for six rats or mice. Statistical comparison was performed using ANOVA followed by Dunnett's post test. ${ }^{*} P<0.05$ and ${ }^{* *} P<0.01$ compared with the negative control group. 
Table 2 shows the gastroprotective activity of the plant extracts, in which the total lesion area and relative lesion area were reduced at the dose of $250 \mathrm{mg} / \mathrm{kg}$. All the extracts had significantly lower values when compared with the negative control. It is possible that the extracts possess protective action through the production or maintenance of the mucus against the damage induced by this NSAID.

TABLE 2. Effect of oral administration of plant extracts in acute ulcer induced by NSAID (indomethacin) in mice $(n=6)$

\begin{tabular}{lccc}
\hline Treatments & Dose & $\begin{array}{c}\text { Total area of } \\
\text { lesion }\left(\mathrm{mm}^{2}\right)\end{array}$ & $\begin{array}{c}\text { Relative area } \\
\text { of lesion }(\%)\end{array}$ \\
\hline Negative control & $250 \mathrm{mg} / \mathrm{kg}$ & $2.781 \pm 0.88$ & $1.06 \pm 0.21$ \\
M. tomentosa (peel) & $250 \mathrm{mg} / \mathrm{kg}$ & $0.583 \pm 0.14$ & $0.143 \pm 0.03 * *$ \\
M. tomentosa (seed) & $250 \mathrm{mg} / \mathrm{kg}$ & $0.886 \pm 0.16$ & $0.233 \pm 0.04 * *$ \\
M. pungens (seed) & $250 \mathrm{mg} / \mathrm{kg}$ & $1.531 \pm 0.55$ & $0.334 \pm 0.12^{* *}$ \\
M. pungens (leaves) & $250 \mathrm{mg} / \mathrm{kg}$ & $2.193 \pm 0.33$ & $0.531 \pm 0.08 *$ \\
I. vera (seed) & $250 \mathrm{mg} / \mathrm{kg}$ & $1.212 \pm 0.58$ & $0.2530 .12 * *$ \\
I. vera (pulp) & $250 \mathrm{mg} / \mathrm{kg}$ & $0.761 \pm 0.24$ & $0.193 \pm 0.06 * *$ \\
Positive control & $100 \mathrm{mg} / \mathrm{kg}$ & $0.899 \pm 0.27$ & $0.230 \pm 0.07 * *$ \\
\hline
\end{tabular}

NSAID: nonsteroidal anti-inflammatory drug. Results as mean \pm SEM for six rats or mice. Statistical comparison was performed using ANOVA followed by Dunnett's post test. $* P<0.05$ and $* * P<0.01$ compared with the negative control group.

Each plant extract was separately analyzed in relation to the results for relative area of the lesion (\%). Extracts of $M$. pungens (leaves and seeds) M. tomentosa (peel and seeds) and $I$. vera (pulp and seed) showed gastroprotective activity and obtained significantly better results when compared to the negative control (indomethacin) (Figure 2).

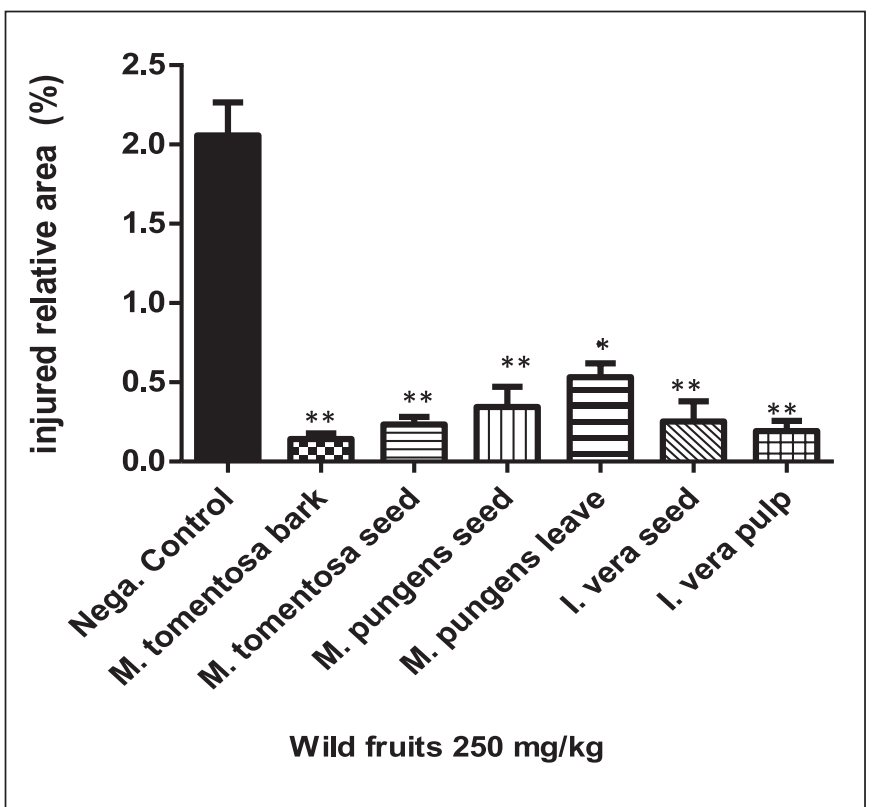

FIGURE 2. Effect of oral administration of plant extracts at a dose of $250 \mathrm{mg} / \mathrm{kg}$ and indomethacin $(100 \mathrm{mg} / \mathrm{kg})$. Statistical comparison was performed using ANOVA followed by Dunnett's post test. ${ }^{*} P<0.05$ and ${ }^{* *} P<0.01$ compared with the negative control group.
Administration of the extracts of M. tomentosa (peel and seeds) and $I$. vera (pulp and seed) were effective in gastroprotection tests, resulting in a significant decrease in relative area of the lesions when compared with the negative control (Figure 2).

\section{DISCUSSION}

The model of acute ethanol-induced ulcers gives significant indications of mechanisms of action of the extracts, which can be associated with antioxidant factors and/or anti-inflammatory factors, and the reduction of acid secretion and mucus production ${ }^{(4,11)}$.

In the ethanol-induced gastric lesions model, there were extensive areas of necrosis and hemorrhage in the gastric mucosa of control animals, which proves the toxicity of this agent. One of the main mechanisms attributed to the toxic effect of ethanol is the alteration in gastric cell homeostasis and tissue damage resulting from its direct action on the mucosa and the formation of free radicals and reactive oxygen species ${ }^{(19,20)}$.

The production of free radicals is controlled by various antioxidants, which may be of endogenous origin (superoxide dismutase) or from the diet, such as polyphenols. Antioxidants are capable of stabilizing or deactivating free radicals before they attack the biological targets of the cell ${ }^{(22)}$.

The results obtained by ethanol-induced induction of acute ulcer assume that the plant extracts studied possess bioactive compounds capable of acting as antioxidants. However, further phytochemical studies are necessary to characterize and quantify these compounds.

Previous studies evidenced the antinociceptive/analgesic activity and the presence of the triterpenes $\alpha$-amyrin and $\beta$-amyrin and some flavonoids in $M$. pungens and $M$. tomentosa leaves ${ }^{(14,16)}$. There is no scientific evidence on pharmacological activity and phytochemical analysis of $I$. vera species.

In nonsteroidal anti-inflammatory drug-induced ulcer model, indomethacin was the NSAID chosen due to its high ulcerogenic potential when compared with other drugs. Although its mechanism of action is not completely understood, it is believed that indomethacin induces gastric damage, mainly due to its systemic effect, inhibiting COX-1 and COX-2 and reducing the local concentration of prostaglandins (PGs), which are involved in mucus and bicarbonate production ${ }^{(10,23)}$.

Extracts of $M$. pungens (leaves and seeds) M. tomentosa (peel and seeds) and I. vera (pulp and seed) showed gastroprotective activity and obtained significantly better results when compared to the negative control (indomethacin). It is supposed that the plant extracts contain bioactive compounds with gastroprotective action, demonstrating a decrease in gastric lesions caused by this NSAID ${ }^{(9)}$.

The role of reactive oxygen species is also described for indomethacin-induced lesions. According to Hassan, Martin and Puidg-Parellada ${ }^{(8)}, 2$ hours after oral administration of indomethacin there was sharp increase in the production of superoxide and hydrogen peroxide in the gastric mucosa. Studies have indicated that flavonoids and terpenes, constituents of the plants in question, exhibit pronounced gastroprotective activity in distinct experimental models of ulcer in rat or mice me,21). $^{(9)}$

\section{CONCLUSION}

This study demonstrates, for the first time, the gastroprotective potential of $M$. pungens, $M$. tomentosa and I. vera extracts. All the extracts showed gastroprotective activity for different parts of the plants, 
with greater emphasis the pulp of $I$. vera, against the aggressors used - ethanol and indomethacin - being more effective against the first.

It is supposed that the wild species studied possess bioactive compounds, possibly terpenes and flavonoids with antioxidant activity, which could help control the levels of reactive oxygen species in the mucosa, protecting the mucosal damage caused by ethanol and indomethacin. These compounds could be capable of influencing the prostaglandins levels, maintaining mucus and bicarbonate production, and protecting the gastric mucosa. Phytochemical studies are necessary to determine the major compounds responsible for the gastroprotective activity. Studies to determine the antioxidant enzymes involved in the processes related to the protective action of the mucous membrane are also relevant.

\section{ACKNOWLEDGEMENTS}

This work was supported by grants from the Brazilian institutions Conselho Nacional de Desenvolvimento Cientifico e Tecnológico (CNPq), and the Coordenação de Aperfeiçoamento de Pessoal de Nivel Superior (CAPES).

Dr. Oscar B. Iza (Universidade do Vale do Itajaí) for the identification of the selected wild fruit trees.

\section{Authors' contributions}

All authors contributed in the experimental part and writing of this study.

Nesello LAN, Campos A, Rosa RL, Andrade SF, Cechinel Filho V. Triagem de plantas frutíferas silvestres com ação gastroprotetora em modelos in vivo.

Arq Gastroenterol. 2017;54(2):135-8.

RESUMO - Contexto - Devido ao aumento de pessoas com distúrbios gastrointestinais, a busca de tratamentos alternativos com menos efeitos colaterais é fundamental, assim como a demanda por alimentos ou plantas que possam ajudar a proteger o estomago. Objetivo - O presente estudo teve como objetivo avaliar a ação gastroprotetora dos extratos plantas frutíferas silvestres Myrcianthes pungens (guabiju); Inga vera Willd. (ingá-banana) e Marlierea tomentosa Cambess. (guarapuruna) em modelos farmacológicos in vivo. Métodos - As diferentes partes do fruto foram submetidas separadamente a um processo de maceração em solução metanólica a frio. Foram realizados dois modelos experimentais em camundongos, modelo de úlcera gástrica induzida por anti-inflamatório não-esteroidal (indometacina) e modelo de úlcera gástrica induzida por etanol/HCl, que permitiram avaliar a atividade gastroprotetora dos extratos na dose de $250 \mathrm{mg} / \mathrm{kg}$. Posteriormente, foram determinadas a área total de lesão $\left(\mathrm{mm}^{2}\right)$ e a área relativa lesada (\%). Resultados - Os resultados apresentaram atividade gastroprotetora significativa para todos os extratos estudados frente aos agentes agressores utilizados, etanol e indometacina. Conclusão - Supõe-se que os frutos apresentam compostos bioativos, como as substancias antioxidantes, que atuam sobre os níveis de prostaglandinas, protegendo dos danos causados pelo etanol e indometacina. Os resultados encorajam futuros estudos para isolamento e identificação dos princípios ativos dos frutos.

DESCRITORES - Gastroenteropatias. Compostos fitoquímicos. Etanol. Indometacina.

\section{REFERENCES}

1. Amaral ACF, Kuster RM, Bessa WS, Barnes RA, Kaplan MAC, Wessjohann LA. Flavonoids and other phenolics from the leaves of two Marlierea species (Myrtaceae). Biochem Syst Ecol. 2001;29:653-4.

2. Apel AM, Sobral M, Henriques AT. Composição química do óleo volátil de Myrcianthes nativas da região sul do Brasil. Rev Bras Farmacogn. 2006;16:402-7.

3. Asmari AA, Omani SA, Otaibi MA, Abdulaaly AA, Elfaki I, Yahya KA, et al. Gastroprotective effect of minocycline in experimentally induced gastric ulcers in rats. Int $J$ Clin Exp Med. 2014;7:586-96.

4. Berté PE, da Silva Lopes J, Comandulli NG, Rangel DW, Monache FD, Cechinel Filho V, et al. Evaluation of the gastroprotective activity of the extracts, fractions, and pure compounds obtained from aerial parts of Rubus imperialis in different experimental models. Naunyn Schmiedebergs Arch Pharmacol. 2014;387:313-19.

5. Bonjovani MR. Taxa respiratória em sementes recalcitrantes de Inga vera Willd. Subsp. Affinis (Dc.) T.D. Pennington. [Thesis]. Botucatu: Instituto de Biociências de Botucatu, Universidade Estadual Paulista - UNESP; 2011

6. Dalla Nora CD, Jablonski A, Rios AO, Hertz PF, Jong EV, Flores SH. The characterization and profile of the bioactive compounds in red guava (Psidium cattleyanum Sabine) and guabiju (Myrcianthes pungens (O. Berg) D. Legrand). Int J Food Sci Technol. 2014;49:1842-9.

7. Deore AB, Sapakal VD, Dashputre NL, Naikwade NS. Antiulcer activity of Garcinia indica linn fruit rinds. J Appl Pharm Sc. 2011;1:151-4.

8. Hassan A, Martin E, Puig-Parellada P. Role of antioxidants in gastric mucosal damage induced by indomethacin in rats. Methods Find Exp Clin Pharmacol. 1998;20:849-54.

9. Klein Júnior LC, Santin JR, Niero R, de Andrade SF, Cechinel Filho V. The therapeutic lead potential of metabolites obtained from natural sources for the treatment of peptic ulcer. Phytochem Rev. 2012;11:567-616.

10. Laine L, Takeuchi K, Tarnawski A. Gastric mucosal defense and cytoprotection: bench to bedside. Gastroenterology. 2008;135:41-60.

11. Lemos M, Santin JR, Klein Júnior LC, Niero R, Andrade SF. Gastroprotective activity of hydroalcoholic extract obtained from the leaves of Brassica oleracea var. acephala DC in different animal models. J Ethnopharmacol. 2011; 138:503-7.
12. Limberger RP, Sobral M, Henriques AT, Menut C, Bessière JM. Óleos voláteis de espécies de Myrcia nativas do Rio Grande do Sul. Quím Nova. 2006;27:916-9.

13. Liu SC, Lin JT, Wang CK, Chen HY, Yang DJ. Antioxidant properties of various solvent extracts from lychee (Litchi chinenesis Sonn) flowers. Food Chem. 2009;114:577-81.

14. Messias KLS, Campos Buzzi F, Fischer LGO, Malheiros A, Delle Monache F, Cechinel Filho V. Chemical composition and analgesic activity of the leaves and branches of Marlierea tomentosa Camb. Quim Nova. 2008;31:1747-9.

15. Mizui T, Doteuchi M. Effect of polyamines on acidified ethanol-induced gastric lesion in rats. Jpn J Pharmacol. 1983;33:939-45.

16. Nesello LAN, Campos A, Capistrano K, de Campos Buzzi F, Cechinel Filho V. Chemical composition and antinociceptive activity of Myrcianthes pungens leaves. IJARNP. 2016;9:14-9.

17. Paguigan ND, Castillo DHB, Chichioco-Hernandez CL. Atividade anti-úlcera de plantas leguminosas. Arq Gastroenterol. 2014;51:64-68.

18. Rainsford KD. Biochemical gastroprotection from acute ulceration induced by aspirin and related drugs. Biochem Pharmacol. 1980;29:1281-9.

19. Repetto MG, Llesuy SF. Antioxidant properties of natural compounds used in popular medicine for gastric ulcers. Brazi J Med Biol Res. 2002;35:523-34.

20. Rozza AL, Moraes Tde M, Kushima H, Tanimoto A, Marques MO, Bauab TM, et al. Gastroprotective mechanisms of Citrus lemon (Rutaceae) essential oil and its majority compounds limonene and $\beta$-pinene: Involvement of heat-shock protein-70, vasoactive intestinal peptide, glutathione, sulfhydryl compounds, 106 nitric oxide and prostaglandin E2. Chem Biol Interac. 2011;189:82-9.

21. Santin JR, Lemos M, Klein Júnior LC, Niero R, de Andrade SF. Antiulcer effects of Achyrocline satureoides (Lam.) DC (Asteraceae) (marcela), a folk medicine plant, in different experimental models. J Ethnopharmacol. 2010;130:334-9.

22. Schwanz M. Avaliação química e biológica de Maytenus dasyclada Mart. e Maytenus cassineformis Reissek (Celastraceae). [Dissertation]. Porto Alegre: Centro de Ciências Farmacêuticas, Universidade Federal do Rio Grande do Sul; 2012.

23. Suleyman H, Albayrak A, Bilici M, Cadirci E, Halici Z. Different mechanisms in formation and prevention of indomethacin-induced gastric ulcers. Inflammation. 2010;33:224-34 